\title{
Evaluation of seismic performance of reinforced concrete (RC) buildings under near-field earthquakes
}

\author{
Hassan Moniri ${ }^{1}$
}

Received: 30 April 2016/ Accepted: 22 October 2016/Published online: 2 January 2017

(c) The Author(s) 2017. This article is published with open access at Springerlink.com

\begin{abstract}
Near-field ground motions are significantly severely affected on seismic response of structure compared with far-field ground motions, and the reason is that the nearsource forward directivity ground motions contain pulselong periods. Therefore, the cumulative effects of far-fault records are minor. The damage and collapse of engineering structures observed in the last decades' earthquakes show the potential of damage in existing structures under near-field ground motions. One important subject studied by earthquake engineers as part of a performance-based approach is the determination of demand and collapse capacity under near-field earthquake. Different methods for evaluating seismic structural performance have been suggested along with and as part of the development of performance-based earthquake engineering. This study investigated the results of illustrious characteristics of near-fault ground motions on the seismic response of reinforced concrete (RC) structures, by the use of Incremental Nonlinear Dynamic Analysis (IDA) method. Due to the fact that various ground motions result in different intensity-versus-response plots, this analysis is done again under various ground motions in order to achieve significant statistical averages. The OpenSees software was used to conduct nonlinear structural evaluations. Numerical modelling showed that near-source outcomes cause most of the seismic energy from the rupture to arrive in a single coherent long-period pulse of motion and permanent ground displacements. Finally, a vulnerability of RC building can be evaluated against pulse-like near-fault ground motions effects.
\end{abstract}

Hassan Moniri

hassan.moniri@students.emu.edu.tr

1 Department of Civil Engineering, Eastern Mediterranean University, Famagusta, Cyprus
Keywords Near-fault · Reinforced concrete (RC) building · Fling step - Incremental dynamic analysis (IDA) $\cdot$ Seismic demands

\section{Introduction}

Near-field ground motions are affected by direction of rupture propagation to site (forward directivity effect) and residual displacement due to tectonic deformation (flingstep effect). Forward directivity occurs because the propagation velocity of fault rupture toward a site is close to the shear wave velocity. Fling-step waveforms are characterized by offset displacements in the slip-parallel direction, and large, unidirectional velocity pulses (Alavi and Krawinkler 2001; Stewart et al. 2002; Vafaie et al. 2011). Even though the importance of near-source phenomena is well known, there is no clear definition of the distancemagnitude relation which constitutes the far-fault boundary. Several definitions have been given by, e.g., Campbell (1981), Bolt and Abrahamson (1982), Krinitzky and Chang (1987), Hudson (1988), Ambraseys and Menu (1988), Bommer (1991), Martinez-Pereira and Bommer (1998), Martinez-Pereira (1999), who have made an effort to determine the distance magnitude boundary based on nearfault records from destructive earthquakes. Several parameters, such as PGA and Arias intensity, have been used to study the amplitude, energy, frequency content, and duration of the strong motion records (Arias 1970; Yang and Wang 2012; Spyrakos et al. 2008).

The failure of modern engineered structures observed within the near-fault region of the 1994 Northridge earthquake revealed the vulnerability of existing buildings against pulse-type ground motions. The effect of vertical components of ground motion on structures in near-source 
areas focused the attention in the past decades, on the best of field observations concerning the damage which was produced by severe vertical vibrations, e.g., Elnashai and Papazoglou (1997). Somerville et al. (1997) found that the damage potential in the near-fault ground motion is extremely affected by the radiation pattern of the fault rupture, as well as differences between the fault-normal and fault-parallel components of horizontal ground motion. Additionally, the strong directivity effects during the 1999 Kocaeli, Duzce, and Chi-Chi earthquakes renewed attention on the consequences of near-fault ground motions on structures (Kalkan and Kunnath 2006). Mavroeidis and Papageorgiou (2003) have proposed a quite extended range of wavelets to an analytical model of ground motion pulses modeled. It is broadly accepted that structures are susceptible to more damage under pulse-like near-fault earthquakes in comparison to far-fault ground motion. The expected acceleration amplitude of the earthquake is forcefully related to the focal depth of small to moderate magnitude earthquakes in a region close to the source (Spyrakos et al. 2008; Hall et al. 1995).

Rupture directivity is found to increase the low-frequency content of ground motion only at distances less than about $20 \mathrm{~km}$ (Rathje et al. 2004). From the performance-based design (PBD) point of view, the pulse-like motion induced by forward rupture directivity, Bommer and Mendis (2005), explored the differences amongst the spectral scaling factors of displacement which specified with current codes. Study of the effects of rupture directivity on near-fault recordings from recent earthquakes revealed that large long-period pulse is a narrow-band pulse with a period that increases with magnitude (Somerville 2003). Rupture directivity pulses of earthquake in the magnitude range of $\mathrm{Mw}$ 6.7-7.0 are compared with pulses from earthquakes in the magnitude range of 7.2-7.6 the narrow-band nature of these pulses causes their elastic response spectra to have peaks (Somerville 2003).

The aim of this research was to acquire new information about the responses of moment RC frames to near-fault ground motions and the extent of differences existing in comparison with those of far-fault ground motions. More specifically, this study focuses on the results which are related to the following critical parameters like maximum top displacements, inter-storey drift ratios (IDR), probability of collapse and response using the incremental dynamic analysis (IDA) method. It has been used in many applications as for evaluation of the seismic performance of structures, for studies related to damage measure and for the validation of simplified procedures for the prediction of approximate IDA curves (Hatzigeorgiou and Liolios 2010).

\section{Pulse-like ground motions}

An earthquake is a shear dislocation that begins at a point on a fault and spreads at a velocity that is almost as large as the shear wave velocity. The propagation of fault rupture toward a site at a velocity close to the shear wave velocity causes most of the seismic energy from the rupture to arrive in a single large pulse of motion that occurs at the beginning of the record (Somerville et al. 1997; Archuleta and Hartzell 1981).

Actually, pulse-like near-fault earthquakes occurring due to directivity have been widely studied. According to the existing pulse in velocity time history, this type of earthquake is described in the normal direction to the fault line and usually occurs in an area located a short distance to the fault (Somerville 2003). Understanding the effects of this earthquake on structures is very important because it has been experienced that the damage caused is on the high side. Period $\left(T_{\mathrm{p}}\right)$ along with velocity pulse is one of the main characteristics of pulse-like earthquakes. Based on studies, $T_{\mathrm{p}}$ can be considered a good approximation of the period in which the velocity response spectrum reaches its maximum value. There are two approaches on the effects of near-field ground motions on structures. First, in long periods, ground motions normal to the fault line have greater spectrum values as compared with parallel motion to the fault line. Motions parallel and normal to the fault lines are more or less distinct. In addition, maximum displacement of the normal to the fault component occurs at different times when compared to that parallel to the fault component. Thus, it is not possible to obtain the vector sum of their maximums. Second, in near-field earthquakes, the structures are severely shaken as a result of the existence of long pulses. These pulses can cause a large displacement in the structure which has periods close to the pulses (Chopra and Chintanapakdee 2001; Komachi and Tabeshpour 2011; Rathje et al. 2004).

In this study, $T_{\mathrm{p}}$ is presented as the period combined with the peak of $S_{\mathrm{v}}$. It is needs to be said that the correlation between the two $T_{\mathrm{p}}$ is near to 0.85 (Bray and Rodriguez-Marek 2004; Sinan et al. 2005; Tothong and Cornell 2008).

\section{Collapse capacity}

To obtain the collapse capacity related to a particular ground motion, the structural system is analyzed under increasing relative intensity values, expressed as $(\mathrm{Sa} / g) / \eta$ for SDOF systems. The intensity of the ground motion $(\mathrm{Sa})$ is the $5 \%$ damped spectral acceleration in the elastic period 
Table 1 "Columns and beams" section specifications

\begin{tabular}{|c|c|c|c|c|c|c|c|}
\hline \multirow[t]{2}{*}{ Model's } & \multirow[t]{2}{*}{ Storey } & \multicolumn{2}{|l|}{ Column } & \multirow[t]{2}{*}{ Storey } & \multicolumn{3}{|l|}{ Beam } \\
\hline & & Size & Reinf & & Size & Top Reinf & Bot Reinf \\
\hline \multirow[t]{3}{*}{6 storeys } & 1,2 & $60 \times 60$ & $32 \Phi 20$ & $1-3$ & $60 \times 40$ & $3 \Phi 20$ & $3 \Phi 20$ \\
\hline & 3,4 & $50 \times 50$ & $20 \Phi 20$ & $4-6$ & $50 \times 40$ & $3 \Phi 20$ & $3 \Phi 20$ \\
\hline & 5,6 & $40 \times 40$ & $12 \Phi 20$ & & & & \\
\hline \multirow[t]{4}{*}{10 storeys } & 1 & $70 \times 70$ & $40 \Phi 20$ & $1-6$ & $65 \times 40$ & $3 \Phi 20$ & $3 \Phi 20$ \\
\hline & $2-4$ & $60 \times 60$ & $32 \Phi 20$ & $7-10$ & $55 \times 40$ & $3 \Phi 20$ & $3 \Phi 20$ \\
\hline & $5-8$ & $50 \times 50$ & $20 \Phi 20$ & & & & \\
\hline & 9,10 & $40 \times 40$ & $12 \Phi 20$ & & & & \\
\hline \multirow[t]{4}{*}{15 storeys } & $1-5$ & $70 \times 70$ & $40 \Phi 20$ & $1-10$ & $70 \times 40$ & $4 \Phi 20$ & $3 \Phi 20$ \\
\hline & $6-8$ & $60 \times 60$ & $32 \Phi 20$ & $11-15$ & $60 \times 40$ & $4 \Phi 20$ & $3 \Phi 20$ \\
\hline & $9-12$ & $50 \times 50$ & $20 \Phi 20$ & & & & \\
\hline & $13-15$ & $40 \times 40$ & $12 \Phi 20$ & & & & \\
\hline
\end{tabular}

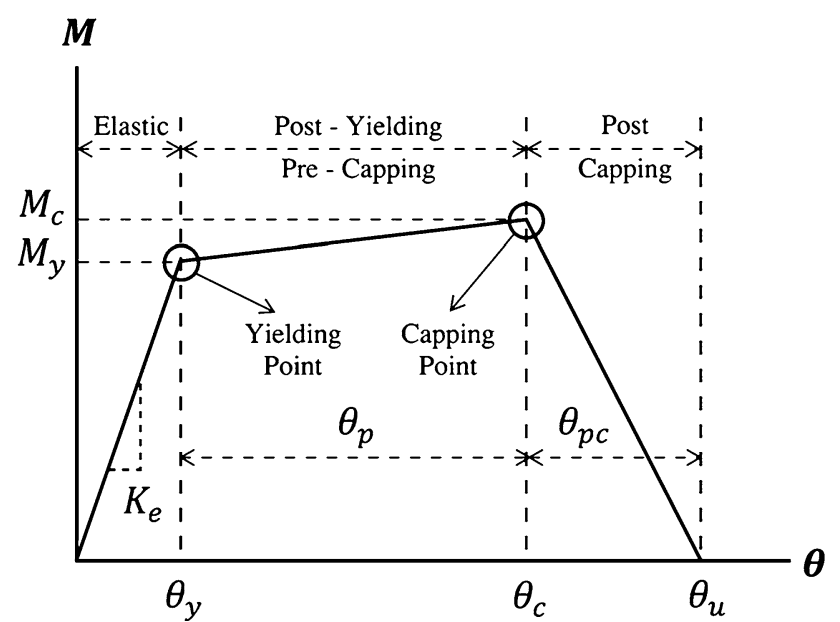

Fig. 1 Model offered by Ibarra and Krawinkler (IKM) (Tothong and Cornell 2008)

of the SDOF system (without P- $\Delta$ effects), while $\eta=F_{\mathrm{y}} /$ $W$ is the base shear strength of the SDOF system which is normalized by its seismic weight. The relative intensity can be plotted against the EDP of interest, resulting in $(\mathrm{Sa} / g) /$ $\eta$ - EDP curves.

For MDOF structures, the relative intensity is expressed as $\left[\mathrm{Sa}\left(T_{1}\right) / g\right] / \gamma$, where $\mathrm{Sa}\left(T_{1}\right) / g$ is the normalized spectral acceleration in the structure's fundamental period without $\mathrm{P}-\Delta$ effects, and the parameter $\gamma$ is the base shear coefficient $V_{\mathrm{y}} / W$, which is equivalent to $\eta$. If there be an increase in the ground motion intensity and the system strength is kept constant, the resulting $(\mathrm{Sa} / g) /$ $\eta$ - EDP or $\left(\left[\mathrm{Sa}\left(T_{1}\right) / g\right] / \gamma-\mathrm{EDP}\right)$ curves represent incremental dynamic analyses (IDAs) (Vamvatsikos and Cornell 2002).

In case the ground motion intensity is kept constant (given hazard) and the strength of the system is reduced, the resulting $(\mathrm{Sa} / g) / \eta-\mathrm{EDP}$ or $\left(\left[\mathrm{Sa}\left(T_{1}\right) / g\right] / \gamma-\mathrm{EDP}\right)$ curves represent EDP demands for various strength levels and are referred to as "strength variation curves". In this case, $(\mathrm{Sa} / g) / \eta$ is equal to the conventional strength reduction factor, $R$, for structures without over strength. Note that when the strength is decreased the entire backbone curve scales down.

\section{Numerical models and structures analyzed}

Building models in this study consisted of 6,10 and 15 story buildings. The overall height of the buildings of 6 , 10 and 15 story is, respectively, 18,30 and $45 \mathrm{~m}$. Compressive strength of concrete and yield strength of steel is 30 and $400 \mathrm{MPa}$, respectively. At all storeys, uniform dead and live loads on the structure are 6 and $2\left(\mathrm{kN} / \mathrm{m}^{2}\right)$. respectively. The importance factor is equal to 1 . The effective seismic weight includes the total dead load without involving the live load. Accidental torsion is considered equal to $5 \%$ of the dimension of the structure perpendicular to the direction of the applied earthquake forces (American Society of Civil Engineers (ASCE) 2000). Following the requirements of guideline, dimensions of structural members such as beams, columns and shear walls and the rebar used are specified. The columns have been placed in raft foundation to decrease translation and rotation at the footing to zero. At all floors, in ceiling systems, concrete slab thickness of $8 \mathrm{~cm}$ is considered. Members' specifications of the building models are listed in Table 1. The nonlinear evaluations are carried out using a typical two-dimensional frame from each of the buildings (Chopra 2012). The computer simulations are carried out using the open source finite-element platform, OpenSees (Mckenna et al. 2000). A force-based nonlinear displacement beam-column element that utilizes a layered "fiber" section is utilized to model all components of the frame models. It is assumed that flexural nonlinear behavior is concentrated at the ends of beams and 

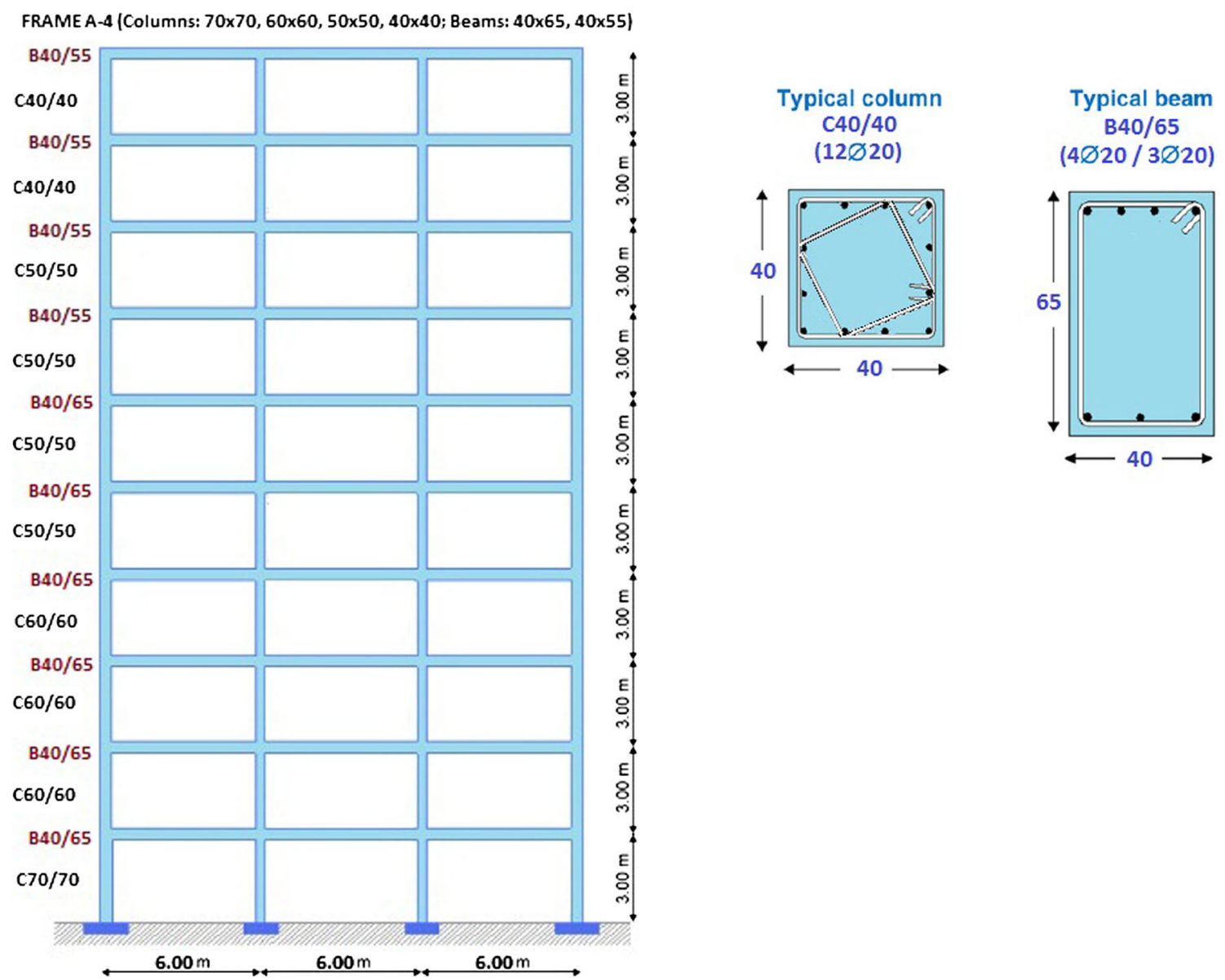

Fig. 2 Sample 10-storey RC models employed for the IDA analyses

Table 2 Specifications of far-fault ground motion records

\begin{tabular}{|c|c|c|c|c|c|c|c|c|c|c|}
\hline No. & Year & Earthquake & $\mathrm{M}_{\mathrm{W}}$ & $\mathrm{Mech}^{\mathrm{a}}$ & Station & GM characteristics & $\operatorname{Dist}^{\mathrm{b}}(\mathrm{km})$ & Site class ${ }^{\mathrm{c}}$ & Datasrc $^{\mathrm{d}}$ & PGA $(g)$ \\
\hline 1 & 1952 & Kern county & 7.5 & TH/REV & Taft & Far-fault & 81.0 & $\mathrm{D}$ & 1 & 0.178 \\
\hline 2 & 1978 & Tabas & 7.4 & TH/REV & Dayhook & Far-fault & 107 & & 1 & 0.400 \\
\hline 3 & 1979 & Imperial-Valley & 6.5 & SS & Calexico & Far-fault & 90.6 & D & 1 & 0.275 \\
\hline 4 & 1989 & Loma Prieta & 7.0 & OB & Presidio & Far-fault & 83.1 & $\mathrm{D}$ & 1 & 0.099 \\
\hline 5 & 1989 & Loma Prieta & 6.9 & $\mathrm{RO}$ & Cliff House & Far-fault & 84.40 & A & 1 & 0.107 \\
\hline 6 & 1990 & Manjil & 7.37 & & Abbar & Far-fault & 74.00 & & 1 & 0.510 \\
\hline 7 & 1999 & Kocaeli & 7.4 & & Ambarli & Far-fault & 78.90 & $\mathrm{C}$ & 1 & 0.179 \\
\hline 8 & 1994 & Northridge & 6.7 & $\mathrm{TH}$ & La-Puente & Far-fault & 56.60 & $\mathrm{D}$ & 1 & 0.129 \\
\hline 9 & 1994 & Northridge & 6.7 & $\mathrm{TH}$ & Baldwin-Park & Far-fault & 47.70 & D & 1 & 0.123 \\
\hline 10 & 1992 & Landers & 7.3 & SS & Baker & Far-fault & 87.90 & D & 1 & 0.108 \\
\hline 11 & 1952 & Kern county & 7.5 & TH/REV & Sant. Courthouse & Far-fault & 114.6 & B & 1 & 0.127 \\
\hline 12 & 1986 & N. Palm Springs & 6.2 & SS & Temecula & Far-fault & 64.70 & $\mathrm{D}$ & 1 & 0.121 \\
\hline 13 & 1986 & N. Palm Springs & 6.2 & SS & Anza Tule Canyon & Far-fault & 51.90 & $\mathrm{D}$ & 1 & 0.110 \\
\hline 14 & 1987 & Whittier-Narrows & 6.1 & TH/REV & Glendora & Far-fault & 63.80 & $\mathrm{D}$ & 1 & 0.110 \\
\hline
\end{tabular}

${ }^{a}$ Faulting mechanism: $T H$ thrust, $R E V$ reverse, $S S$ strike-slip, $O B$ oblique, $R N$ reverse-normal, $R O$ reverse-oblique

${ }^{\mathrm{b}}$ Closest distance to fault rupture (i.e., $r_{\mathrm{jb}}$ )

c NEHRP site classifications: (B for $V_{\mathrm{S}} 760-1500 \mathrm{~m} / \mathrm{s}$ ), (C for $\left.V_{\mathrm{S}} 360-760 \mathrm{~m} / \mathrm{s}\right)$, (D for $V_{\mathrm{S}} 180-360 \mathrm{~m} / \mathrm{s}$ )

${ }^{\mathrm{d}}$ Data source 1: PEER (http://peer.berkeley.edu/smcat), 2: Berkeley (http://nisee.berkeley.edu/data/strong_motion/sacsteel/motions/nearfault. html), 3: ERD (http://angora.deprem.gov.tr/), 4: http://scman.cwb.gov.tw/eqv5/special/19990921/pgadata-asci0704.htm, 5: Buffalo (https:// mceer.buffalo.edu/infoservice/reference_services/strongMotionGuide.asp) 
Table 3 Specifications of near-fault ground motion records

\begin{tabular}{|c|c|c|c|c|c|c|c|c|c|c|}
\hline No. & Year & Earthquake & $\mathrm{M}_{\mathrm{W}}$ & $\mathrm{Mech}^{\mathrm{a}}$ & Station & GM characteristics & $\operatorname{Dist}^{\mathrm{b}}(\mathrm{km})$ & $\begin{array}{l}\text { Site } \\
\text { class }^{c}\end{array}$ & Datasrc $^{\mathrm{d}}$ & PGA $(\mathrm{g})$ \\
\hline 1 & 1999 & Chi-Chi & 7.6 & $\mathrm{TH}$ & TCU052 & Fling & 1.84 & $\mathrm{D}$ & 4 & 0.349 \\
\hline 2 & 1999 & Chi-Chi & 7.6 & $\mathrm{TH}$ & TCU052 & Fling & 1.84 & $\mathrm{D}$ & 4 & 0.438 \\
\hline 3 & 1999 & Chi-Chi & 7.6 & $\mathrm{TH}$ & TCU068 & Fling & 3.01 & $\mathrm{D}$ & 4 & 0.501 \\
\hline 4 & 1999 & Chi-Chi & 7.6 & $\mathrm{TH}$ & TCU068 & Fling & 3.01 & $\mathrm{D}$ & 4 & 0.363 \\
\hline 5 & 1999 & Kocaeli & 7.4 & SS & Sakarya & Fling & 3.20 & $\mathrm{C}$ & 3 & 0.415 \\
\hline 6 & 1999 & Chi-Chi & 7.6 & $\mathrm{TH}$ & TCU072 & Fling & 7.87 & $\mathrm{D}$ & 4 & 0.364 \\
\hline 7 & 1999 & Chi-Chi & 7.6 & $\mathrm{TH}$ & TCU128 & Fling & 9.08 & $\mathrm{C}$ & 4 & 0.138 \\
\hline 8 & 1999 & Kocaeli & 7.4 & SS & Izmit & Fling & 4.30 & B & 3 & 0.233 \\
\hline 9 & 1994 & Northridge-01 & 6.69 & REV & LA-Sepulveda VA Hospital & Fling & 6.70 & $\mathrm{C}$ & 5 & 0.464 \\
\hline 10 & 1994 & Northridge- 01 & 6.69 & REV & Arleta-Nordhoff Fire Sta & Fling & 3.30 & $\mathrm{D}$ & 1 & 0.552 \\
\hline 11 & 1994 & Northridge-01 & 6.7 & REV & Rinaldi receiving Sta & Fling & 7.5 & $\mathrm{D}$ & 2 & 0.871 \\
\hline 12 & 1994 & Northridge-01 & 6.7 & REV & Rinaldi receiving Sta & Fling & 7.5 & $\mathrm{D}$ & 2 & 0.387 \\
\hline 13 & 1999 & Chi-Chi & 7.6 & $\mathrm{TH}$ & TCU079 & Fling & 11.0 & $\mathrm{D}$ & 4 & 0.568 \\
\hline 14 & 1999 & Chi-Chi & 7.6 & $\mathrm{TH}$ & TCU078 & Fling & 8.3 & D & 4 & 0.431 \\
\hline
\end{tabular}

${ }^{a}$ Faulting mechanism: $T H$ thrust, $R E V$ reverse, $S S$ strike-slip, $O B$ oblique, $R N$ reverse-normal, $R O$ reverse-oblique

${ }^{\mathrm{b}}$ Closest distance to fault rupture (i.e., $r_{\mathrm{jb}}$ )

${ }^{c}$ NEHRP site classifications: (B for $\left.V_{\mathrm{S}} 760-1500 \mathrm{~m} / \mathrm{s}\right),\left(\mathrm{C}\right.$ for $\left.V_{\mathrm{S}} 360-760 \mathrm{~m} / \mathrm{s}\right)$, (D for $V_{\mathrm{S}} 180-360 \mathrm{~m} / \mathrm{s}$ )

${ }^{\mathrm{d}}$ Data source 1: PEER (http://peer.berkeley.edu/smcat), 2: Berkeley (http://nisee.berkeley.edu/data/strong_motion/sacsteel/motions/nearfault. html), 3: ERD (http://angora.deprem.gov.tr/), 4: http://scman.cwb.gov.tw/eqv5/special/19990921/pgadata-asci0704.htm, 5: Buffalo (https:// mceer.buffalo.edu/infoservice/reference_services/strongMotionGuide.asp)
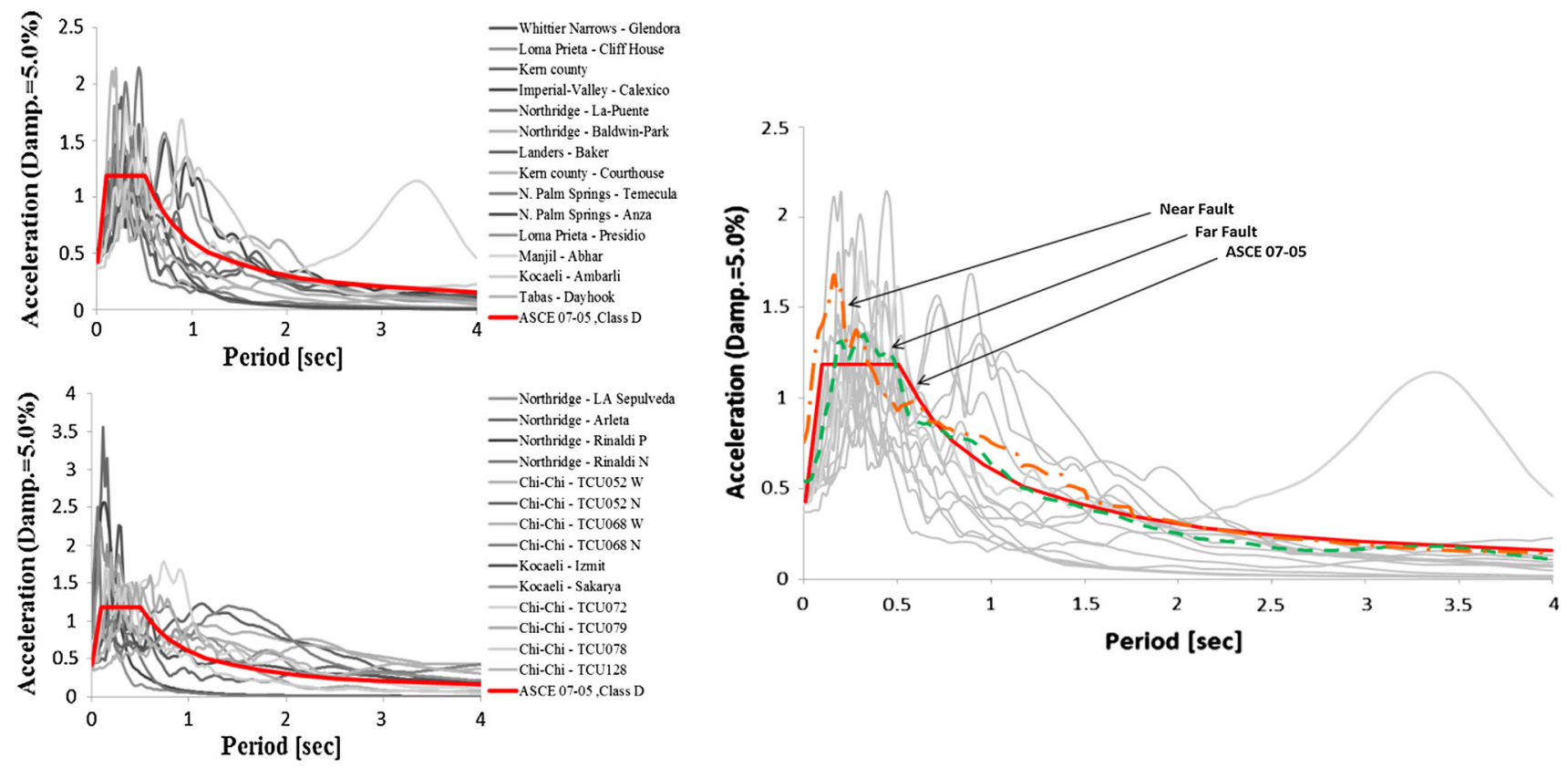

Fig. 3 Far- and near-fault ground motions scaled with ASCE 7-05 standard

columns and is modeled using the modified Ibarra Krawinkler Medina (IKM) deterioration model (Ibarra and Krawinkler 2005; Lignos and Krawinkler 2009) (Fig. 1). Moreover, in this study assume that none of the structural components are not failure by shear critical. Rayleigh damping corresponding to $5 \%$ of critical damping (Bernal et al. 2015) is also applied in first and third modes (Visnjic et al. 2013; Esmaili et al. 2015). 
Fig. 4 Seismic response for 6-storey RC frame under farStorey Drift's profile, $\mathbf{b}$ top displacement profile fault ground motions; a inter-

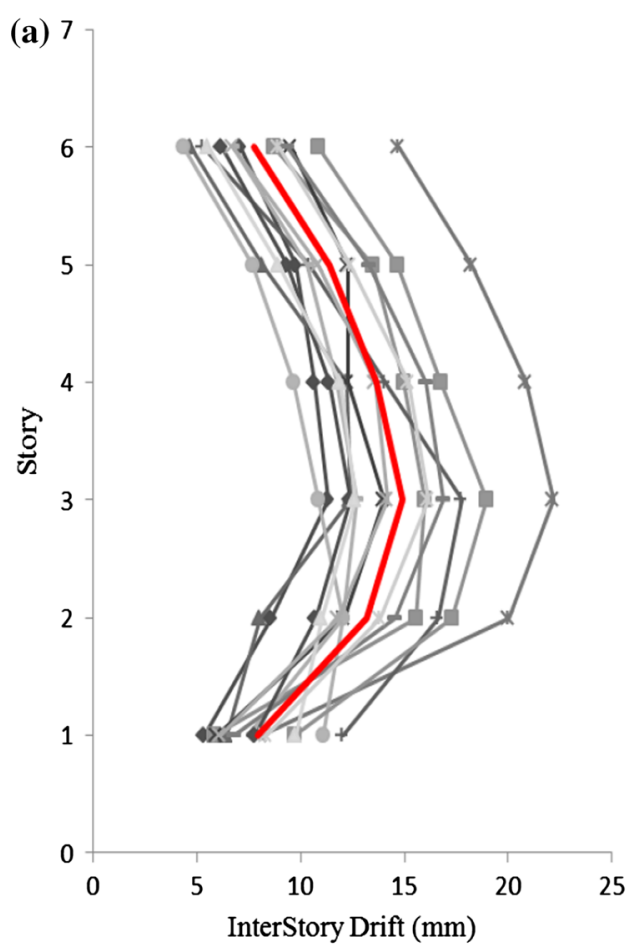

Fig. 5 Seismic response for 6-storey RC frame under nearfault ground motions; a interStorey Drift's profile, $\mathbf{b}$ top displacement profile

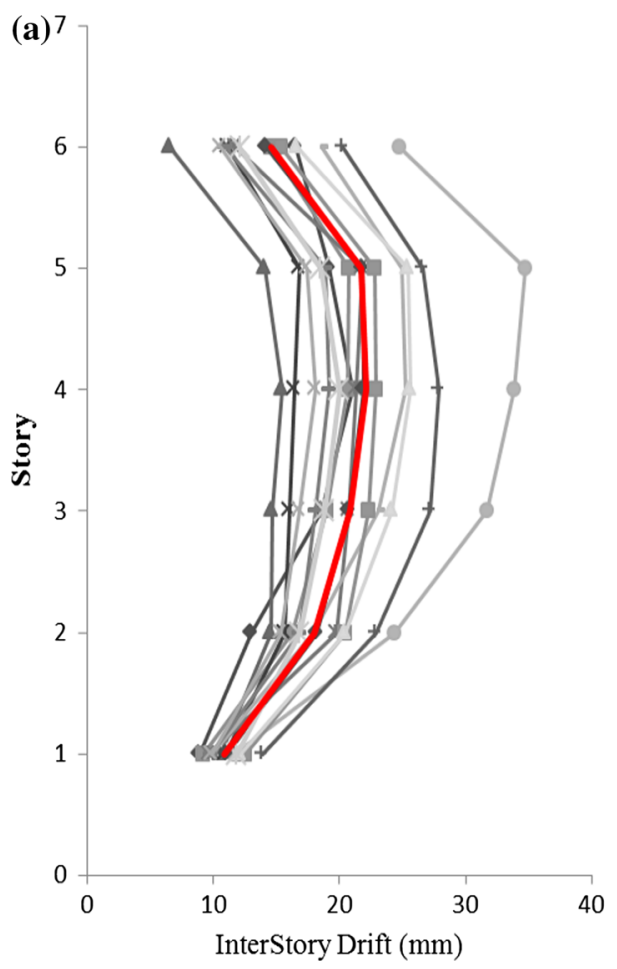

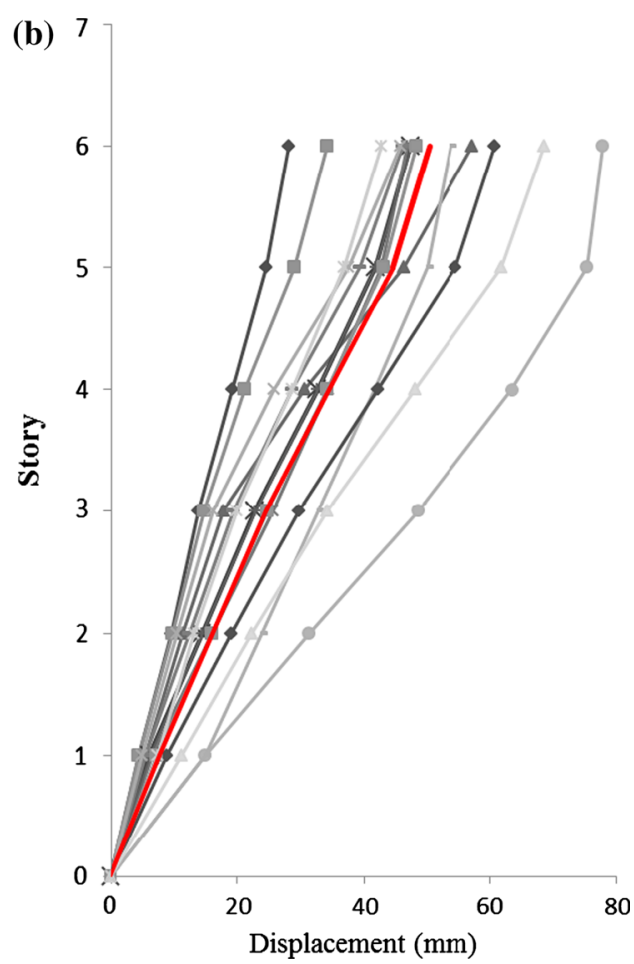

(b) 7

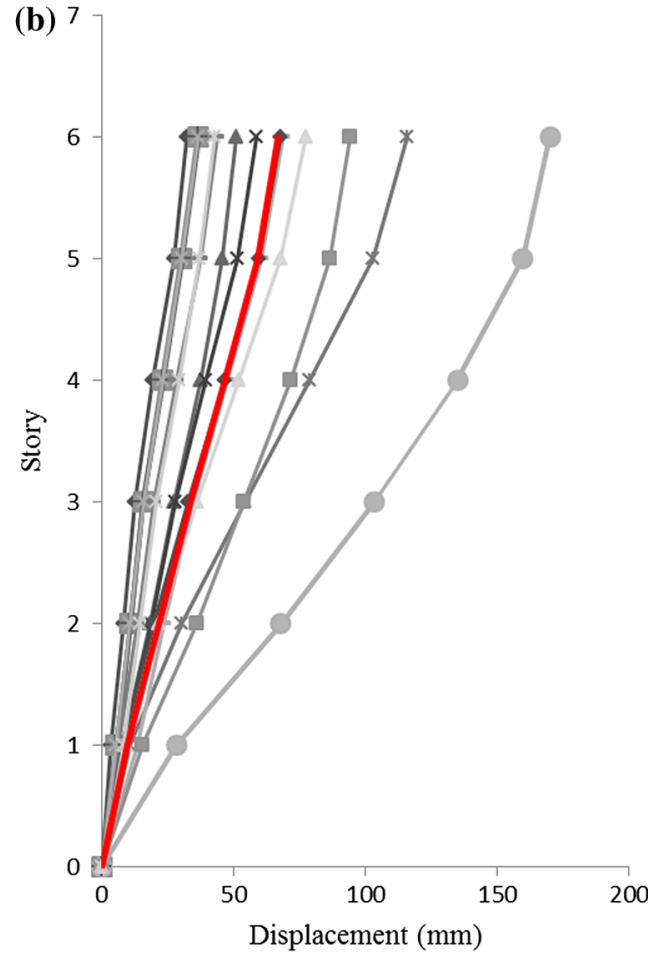

The backbone curve definition is based on typical modified IKM deterioration model where $K_{\mathrm{e}}$ is the initial stiffness, $M_{\mathrm{y}}$ is the yield moment, $M_{\mathrm{c}} / M_{\mathrm{y}}$ is the capping moment ratio, $\theta_{\mathrm{p}}$ is the plastic hinge rotation capacity, and $\theta_{\mathrm{pc}} / \theta_{\mathrm{p}}$ is the post capping rotation capacity ratio, $\theta_{\mathrm{c}}$ is the capping plastic hinge rotation capacity and $\theta_{\mathrm{u}}$ is the ultimate hinge rotation capacity (Esmaili et al. 2015).

Generally, engineering-designed buildings are much stiffer in the upper storeys and, therefore, will be less 
Fig. 6 Seismic response for 10 -storey RC frame under farfault ground motions; a interStorey Drift's profile, b top displacement profile
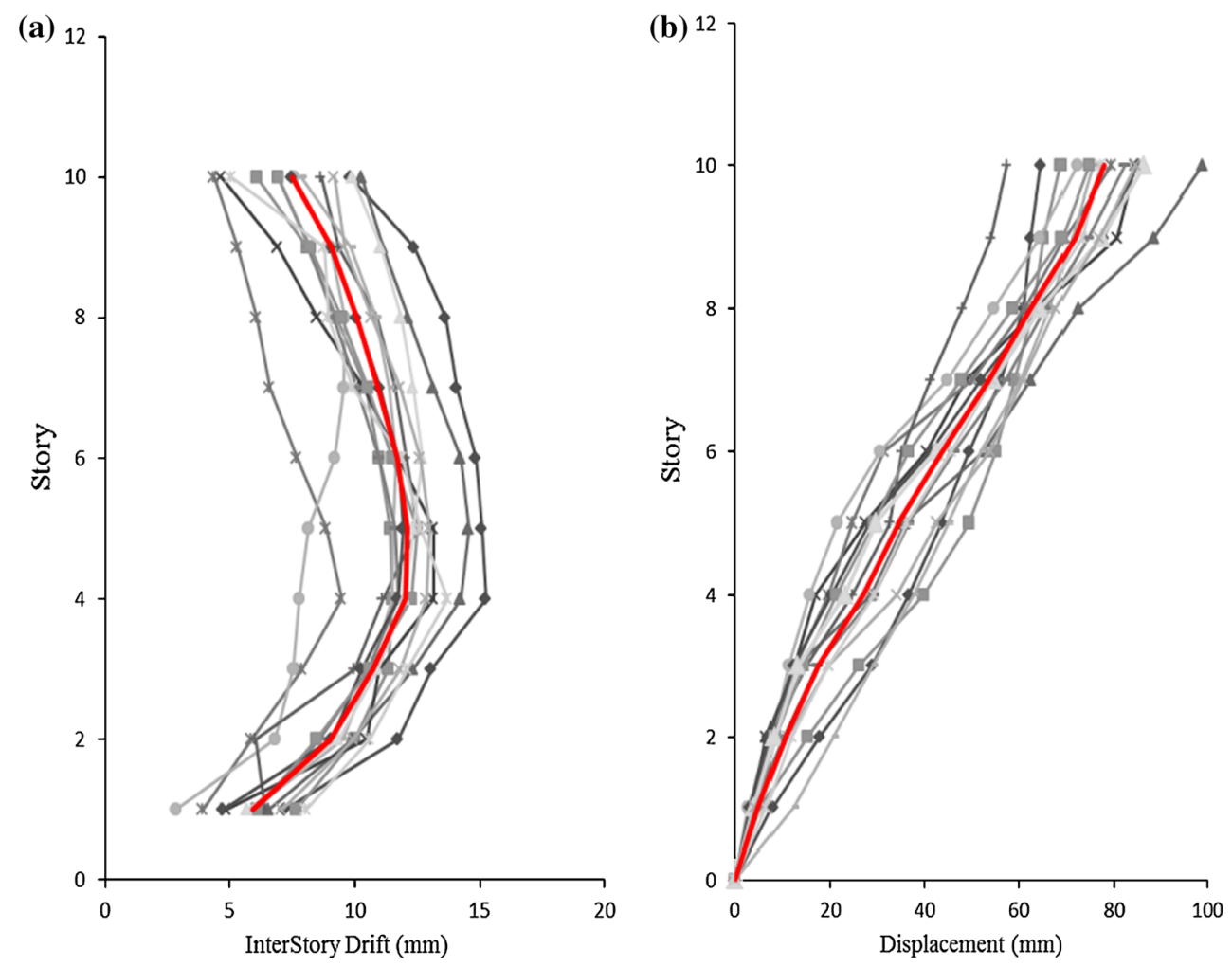

Fig. 7 Seismic response for 10 -storey RC frame under nearfault ground motions; a interStorey Drift's profile, b top displacement profile

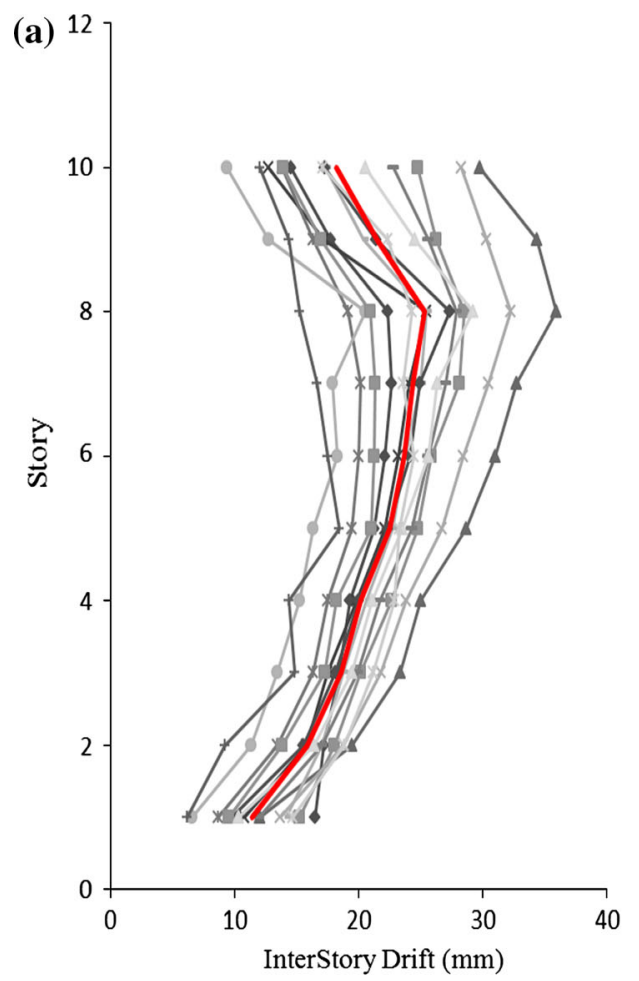

(b)

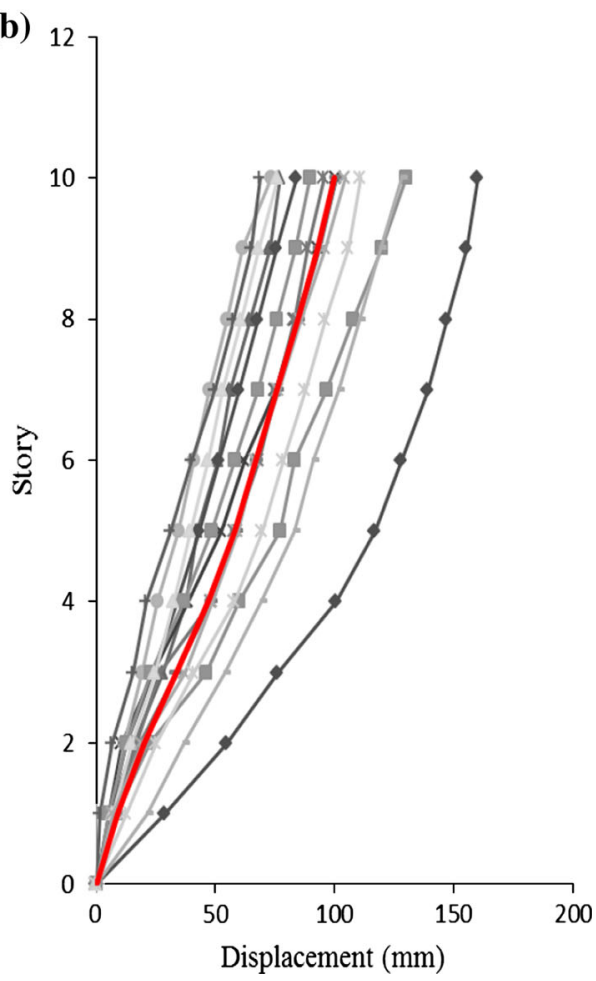

sensitive to higher modes (Tothong and Cornell 2008). But in this paper, upper stories are very flexible because it can make the structure sensitive to higher mode excitations to achieve the same story drift ductility under the parabolic lateral load pattern specified in FEMA-356 (American Society of Civil Engineers (ASCE) 2000) (Fig. 2). 
Fig. 8 Seismic response for 15 -storey RC frame under farfault ground motions; a interStorey Drift's profile, $\mathbf{b}$ top displacement profile
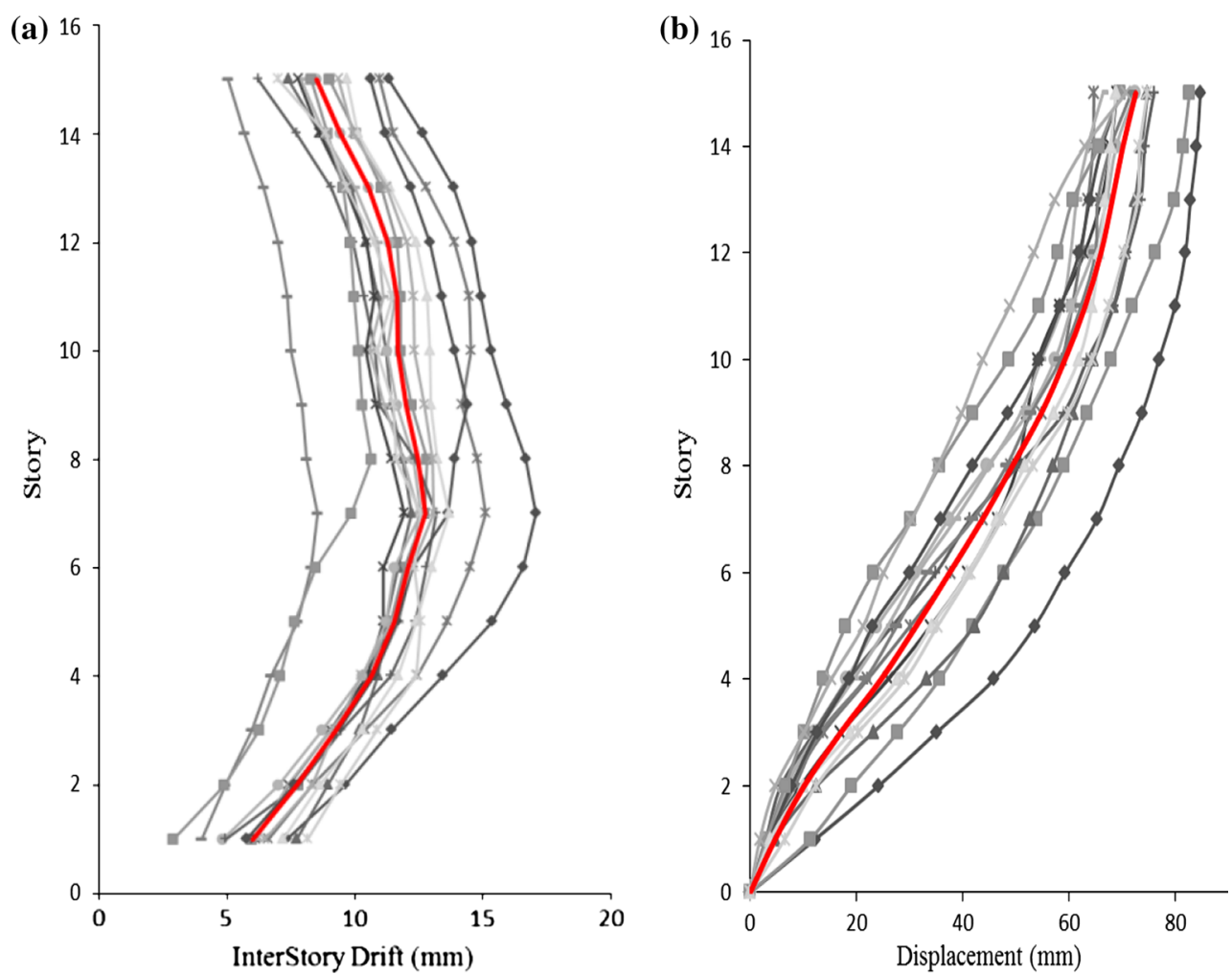

Fig. 9 Seismic response for 15 -storey RC frame under nearfault ground motions; a interStorey Drift's profile, b top displacement profile

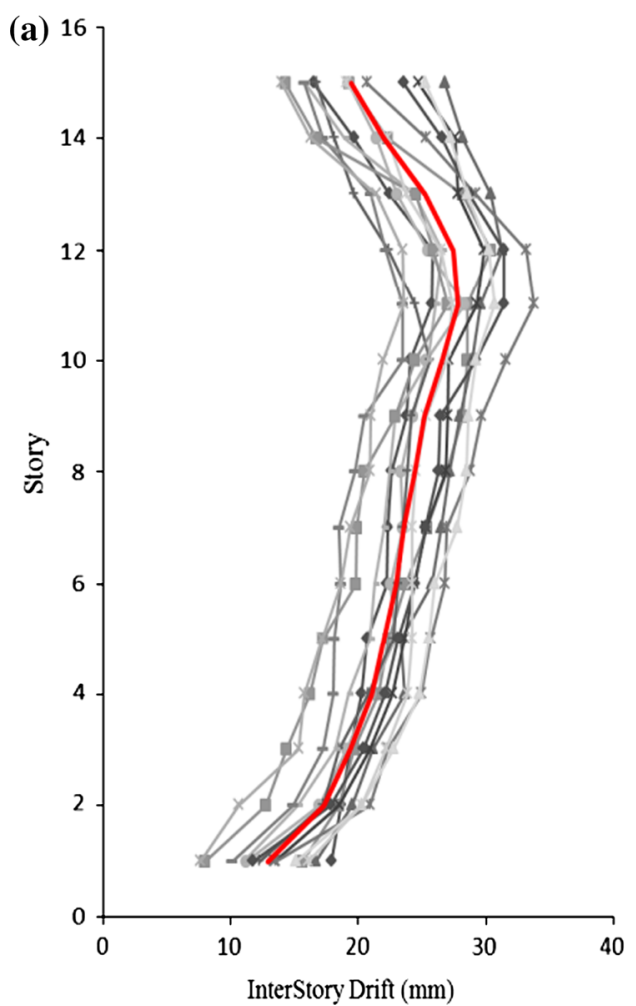


Table 4 Comparing the mean values of the maximum inter-storey drift (IDR) and maximum top displacement (MTD) under near- and far-field ground motion records $(\mathrm{mm})$

\begin{tabular}{lllcc}
\hline Model's & IDR of NF fling & IDR of FF & MTD of NF fling & MTD of FF \\
\hline 6-story & 22.40 & 15.01 & 53.01 & 43.55 \\
10-story & 24.06 & 12.10 & 95.45 & 76.6 \\
15-story & 32.16 & 17.12 & 119.3 & 78.5 \\
\hline
\end{tabular}
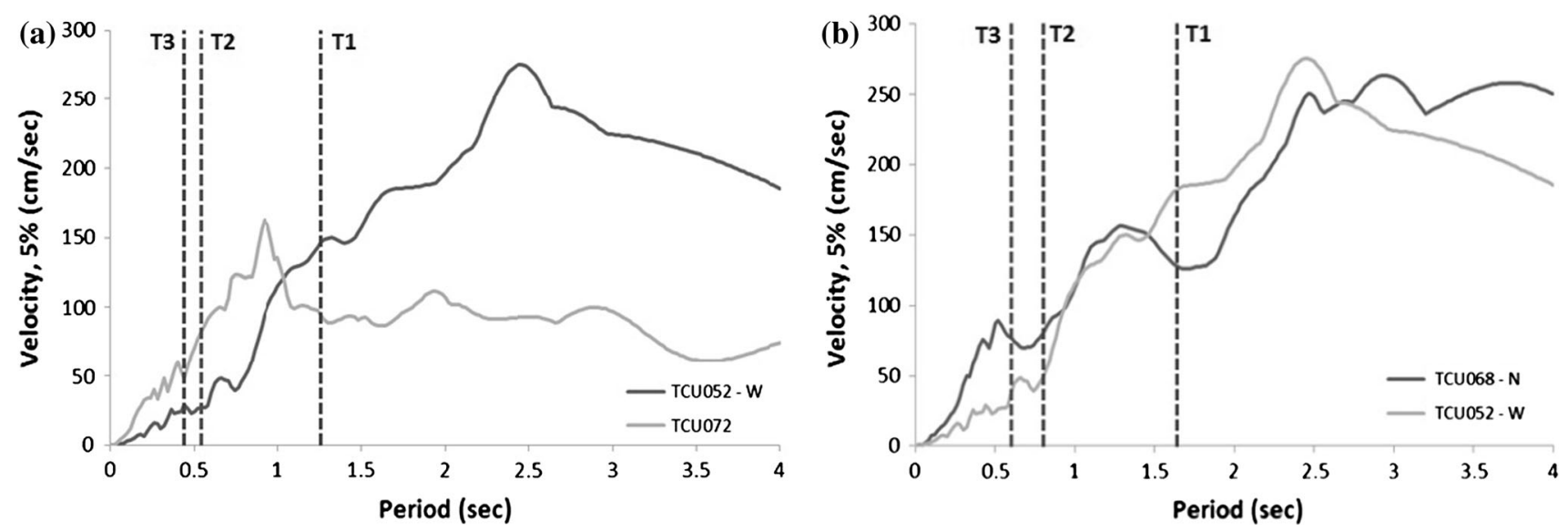

Fig. 10 Velocity spectra of selected ground motions. a 6 storey; b 10 storey

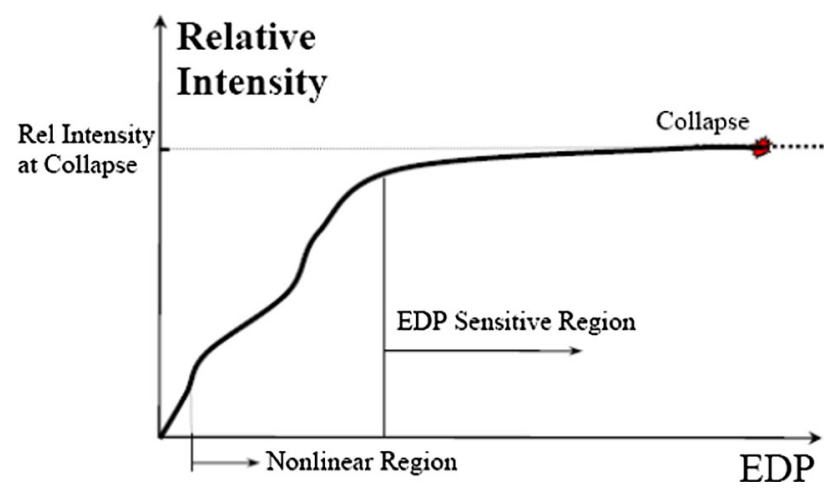

Fig. 11 EDP curve, relative intensity (Vamvatsikos and Cornell 2002)

\section{Ground motion records}

Tables 2 and 3 show the profile of earthquake records used in the present study. As mentioned, 28 ground motion records have been used, including 14 far-field and 14 nearfield ones (Berkeley Database 2016; Database 2016). Farfield ground motions of 6.1-7.5 magnitudes at distances $50-115 \mathrm{~km}$ from the site and recorded on soft or firm soils are the first group of records. The second group involves near-field ground motions of 6.6 and 7.6 magnitude recorded at distances $0.24-11 \mathrm{~km}$ from the site and on soft or firm soils.
In Tables 2 and 3 specifications of the records, including the recording stations, seismic component, moment magnitude, distance to fault and peak ground acceleration (PGA) are given.

\section{Results and discussion}

The results of the analyses of building models affected by near-fault and far-fault ground motion are presented here. The records were studied using incremental dynamic analysis (Fig. 3). The analysis comprises plotting and comparisons of total displacement of story, inter-story drift (IDR) and IDA curves.

It should be noted that each building model is studied under near-fault as well as far-fault ground motion. This resulted in 84 nonlinear time history analyses ( 28 records for each building model). The first index of seismic demand used here is the inter-story drift ratio, defined as the relative displacement between two adjacent floors divided by the height of the story. Non-linear time history analysis results for buildings with moment frames are plotted below, with results pertaining to maximum lateral displacement under both groups of ground motion. For these building models, far-fault motions result in nearly uniform lateral displacement requirements with the exception of a small record in the 10-story building which 
(a)

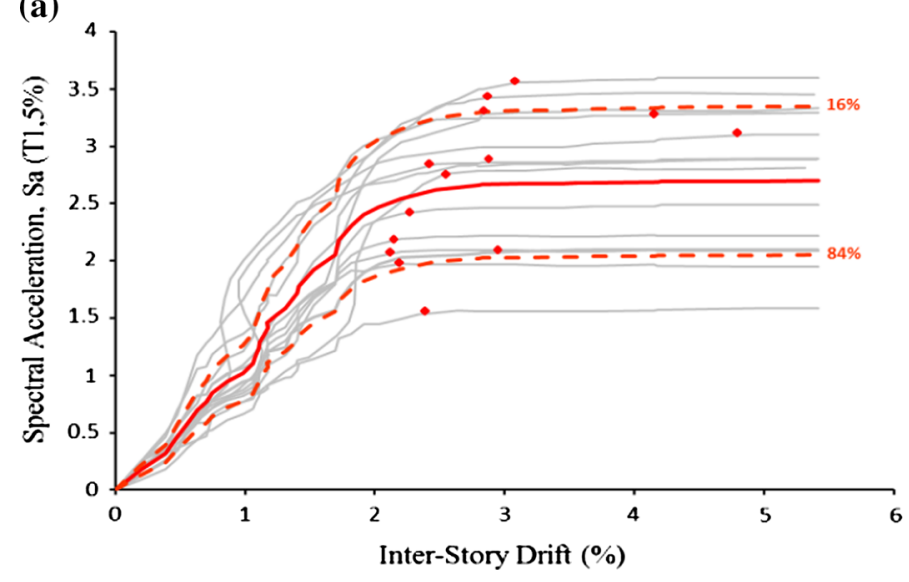

(b)

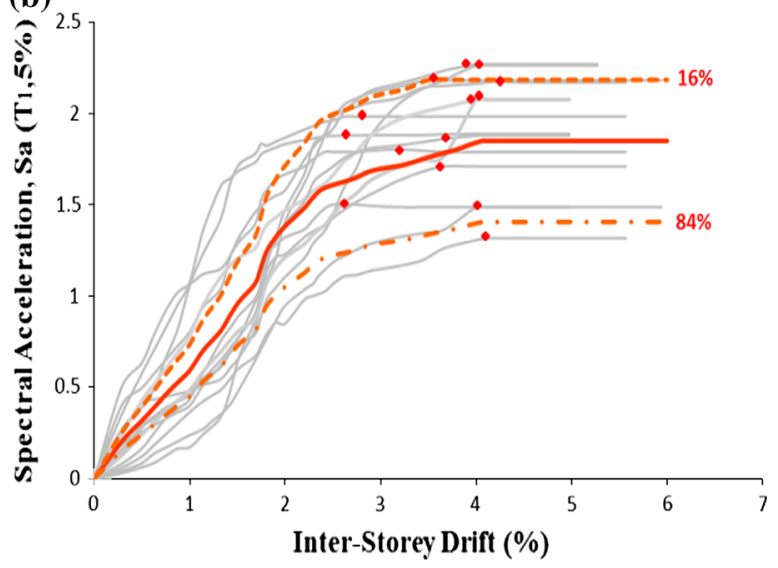

Fig. 12 The summary of IDA curves for 6-storey building: a far-fault ground motions, b near-fault ground motions

(a)

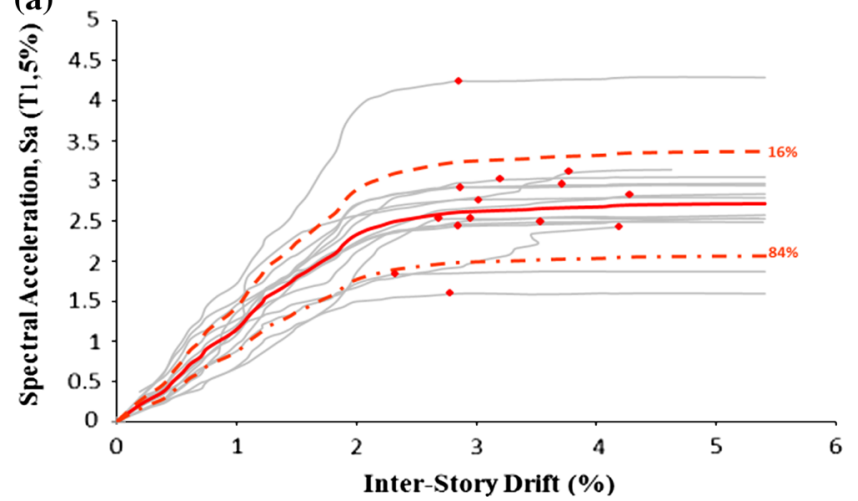

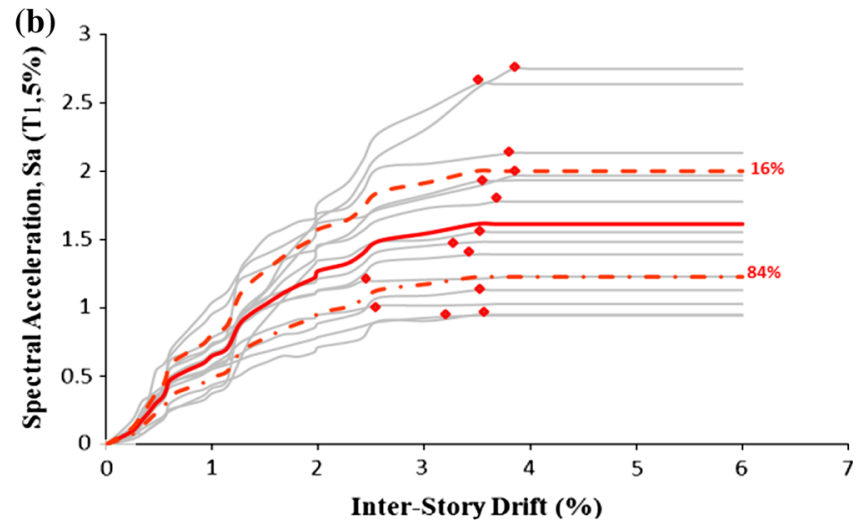

Fig. 13 The summary of IDA curves for 10-storey building: a far-fault ground motions, b near-fault ground motions
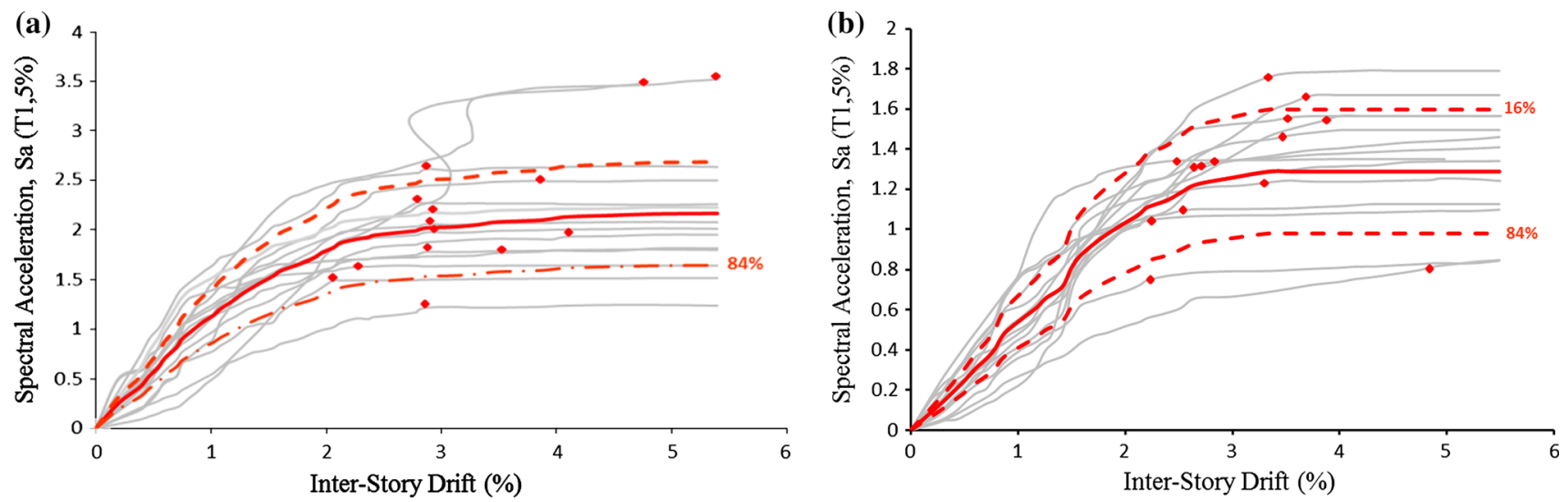

Fig. 14 The summary of IDA curves for 15-storey building: a far-fault ground motions, b near-fault ground motions

will create more displacements. In comparison to far-fault conditions, near-fault conditions produce higher requirements. With near-field ground motions involving fling-step, TCU-52 creates the largest displacement in 6- and 10-story buildings.

\section{Seismic response evaluation of buildings}

Inter-storey relative displacement is one of the important factors affecting failure rate in the structure. Therefore, it is a good measure for assessing the performance of seismic 


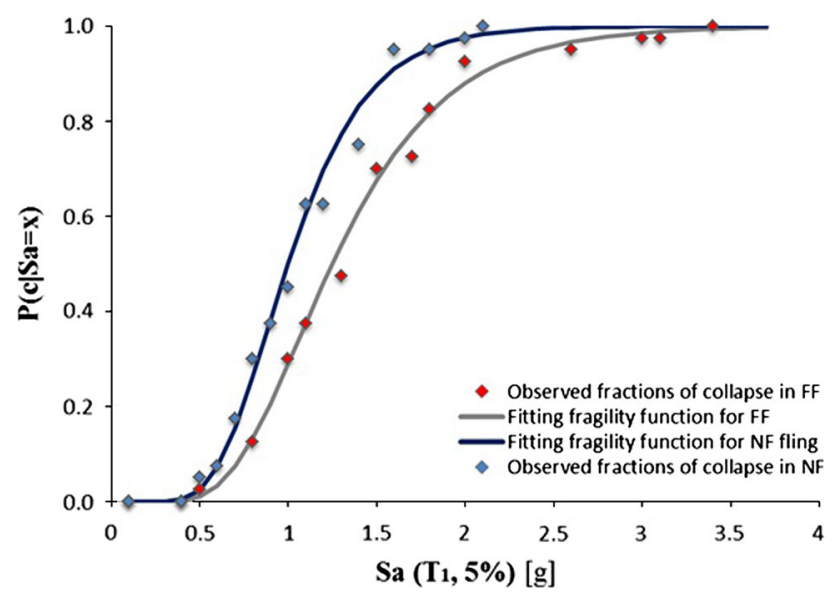

Fig. 15 Probability of collapse using an empirical CDF and a fitted lognormal CDF for 6-storey RC model

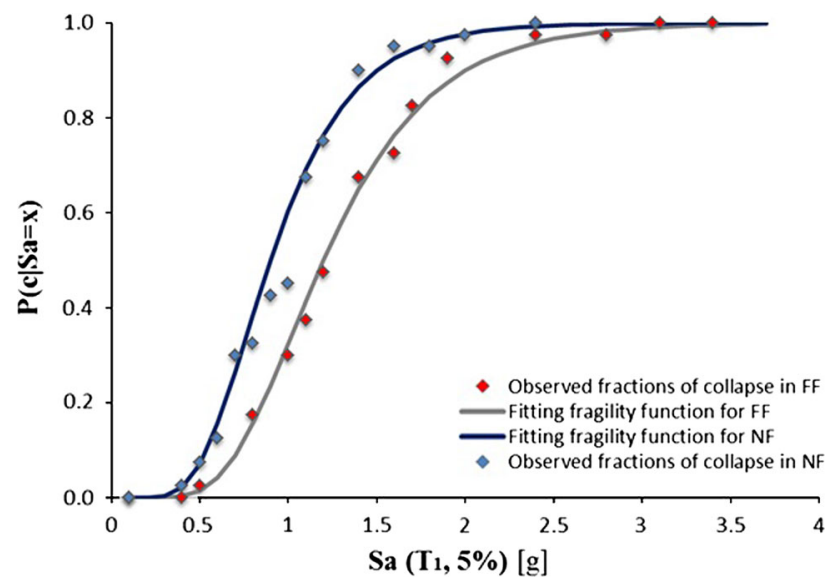

Fig. 16 Probability of collapse using an empirical CDF and a fitted lognormal CDF for 10-storey RC model

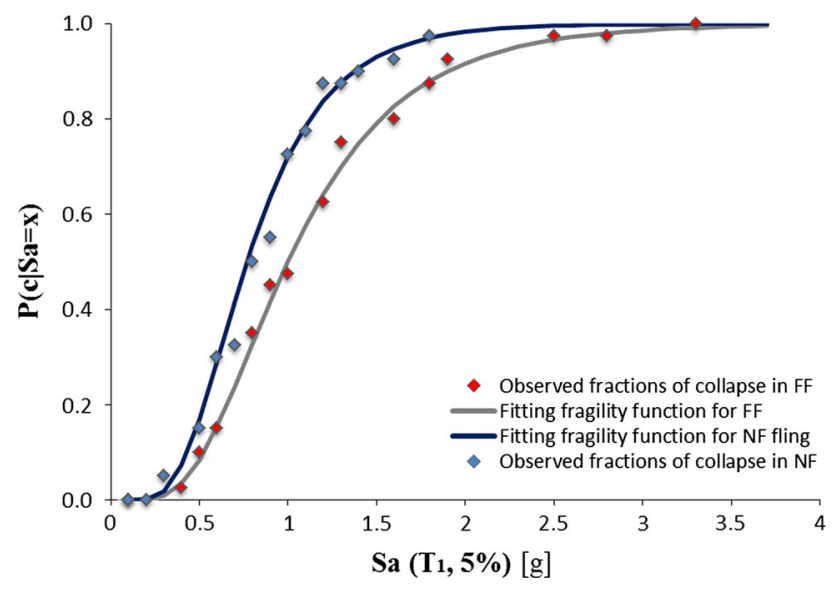

Fig. 17 Probability of collapse using an empirical CDF and a fitted lognormal CDF for 15-storey RC model

resistance of RC frames under pulse-like ground motions. Near-fault ground motions usually have quick blow with high period, which may be identical or near the period of building. In such cases, the building may be exposed to severe deformation. The results of the analyses show this approach. In fact, under the same conditions, further displacements may occur due to near-fault than far-fault earthquakes. This is an important note, especially in highrise buildings (Figs. 4, 5, 6, 7, 8, 9).

By comparing the mean values of the maximum interstory drift ratio (IDR) under near-field and far-field records, it can be seen that for 6-story building, a maximum interstory drift of $22.40 \mathrm{~mm}$ is produced, being 50 percent more than $15.01 \mathrm{~mm}$ due to far-field records and it can be seen that the maximum story displacement of $53.01 \mathrm{~mm}$ is produced, being 22 percent more than $43.55 \mathrm{~mm}$ due to far-field records. In 10-story building, a maximum interstory drift equals to $24.06 \mathrm{~mm}$, which is 98 percent more than $12.10 \mathrm{~mm}$ resulted from far-field records and the maximum story displacement equals to $95.45 \mathrm{~mm}$, which is 24 percent more than $76.6 \mathrm{~mm}$ resulted from far-field records and finally, in 15-story building, a maximum interstory drift equals to $32.16 \mathrm{~mm}$, which is 94 percent more than $17.12 \mathrm{~mm}$ resulted from far-field records and the maximum story displacement equals to $119.3 \mathrm{~mm}$, which is 51 percent more than $78.5 \mathrm{~mm}$ resulted from far-field records. Table 4 shows the mean values of the maximum inter-story drift (IDR) and maximum top displacement (MTD) based on IDA analyses of RC models.

The results show that near-field records introduce significant demands on the upper floors of the structure. Many near-field records have been affected significantly by higher modes, shifting the requirements from the lower to upper storeys. Although the higher mode effects are expected in the response of high-rise buildings, the responses obtained from 6-story buildings showed the nondeniable role of higher modes on the responses of low-rise buildings.

In order to determine the effect of higher modes, it is necessary to examine both the velocity and acceleration spectra of ground motions. Figure 10 shows the spectral velocity of some critical records, producing the most requirements in buildings. It should be noted that the modal periods in a nonlinear system are continuously changing, but the so-called higher mode periods start changing while entering the inelastic range. Modal periods in the elastic range are shown in dotted lines at Fig. 10. Gradually, these lines shift to the right, while the members are yielding. The responses were checked again to find a relation between the information of spectral demand and the observed behavior of the building (Kalkan and Kunnath 2006).

In the records TCU-52 and TCU-68, the structure was most-affected by higher modes, resulting in an increased requirement in the intermediate and upper floors. In the record TCU-52, spectral velocities in modes II and III were significantly more than that of the first mode. For this 
record, the first-mode response of velocity spectra was quite clearly observed. Similarly, by looking at the velocity spectra of TCU-52 and TCU-68, higher mode responses of a 10-storey building can be observed. In summary, it can be said that for near-fault records, the average maximum requirements and dispersion of maximum values of the buildings are higher than those for far-fault records. In general, the effects of higher modes in the records involving fling-step were most evident.

\section{Incremental dynamic analysis results (IDA curves)}

Nonlinear response history analysis (NRHA) can be used for the seismic performance assessment of structures in the IDA framework (Vamvatsikos and Cornell 2002). IDA involves repeatedly running NRHAs using a suite of ground motions scaled to different factors such that the response to each ground motion is obtained at many different intensities. Specifically, for any engineering demand parameter (EDP) used to characterize structural response and intensity measure (IM), e.g. the 5\% damped, first-mode spectral acceleration $\mathrm{Sa}$ $\left(T_{1}, 5 \%\right)(\mathrm{g})$, IDA curves can be generated, consisting of EDP plotted as a function of the IM for each record (Fig. 11).

Conventionally, the response engineering demand parameter (dependent parameter) is plotted on the abscissa, while the IM (independent variable) is plotted on the ordinate. Given these IDA curves, the statistical distribution of response as a function of input can be summarized by curves that represent the 16,50 and $84 \%$ fractiles (Fig. 11). The IDA curves and limit-state capacities across all records can be summarized into 16, 50 and $84 \%$ fractiles by the standard deviation (Fragiadakis and Vamvatsikos 2011). For a better understanding of the different type of ground motion effect on the numerical models, the IDA curves and limit-state capacities across all records was separated in Figs. 12, 13 and 14, respectively.

In the context of incremental dynamic analysis (IDA), the parameters $\hat{\mu}$ and $\hat{\beta}$ can be estimated by taking logarithms of each Sa value associated with collapse of a record. The mean and standard deviation of the $\operatorname{lnS}$ Sa values can then be calculated as used as the estimated parameters (Ibarra and Krawinkler 2005; Baker 2015):

$\hat{\mu}=\frac{1}{n} \sum_{i=1}^{n} \operatorname{lnSa} a_{i}$

$\hat{\beta}=\sqrt{\frac{1}{n-1} \sum_{i=1}^{n}\left(\operatorname{lnSa} a_{i}-\hat{\mu}\right)^{2}}$,

where $n$ is the number of ground motions considered, and $\mathrm{Sa}_{i}$ is the Sa value associated with onset of collapse for the $i$ th ground motion. This approach is denoted "Method A" by Porter et al. (Porter et al. 2007). It has been used to calibrate fragility functions for data other than structural collapse (Aslani and Miranda 2005). A related alternative is to use counted fractiles of the $\mathrm{IM}_{i}$ values, rather than their moments, to estimate $\theta$ and $\beta$ (Baker 2015; Vamvatsikos and Cornell 2004).

For a better understanding of the difference between the performances of the numerical models, the probability of collapse was separated in Figs. 15, 16 and 17, respectively. It is observed that the RC frames (in all models) are more vulnerable than the models were subjected to near-fault ground motions.

\section{Conclusions}

As noted, the present study evaluated the seismic structural performance of reinforced concrete buildings under near- and far-fault ground motion records, based on incremental dynamic analysis methods. For this purpose, 6, 10 and 15 storey buildings have been studied. The numerical modeling carried out in this study showed that the reinforced concrete buildings are under large deformation requirements in the presence of velocity pulses in velocity time history. This requires a considerable amount of energy to be wasted in one or more cycles of Structural Plastics Limited. This requirement makes the structures to meet with limited ductility capacity. In contrast, far-fault motions enter input energy into the system gradually. Although, on average, deformation demands are less than those in the near-fault records, structural systems are subjected to more plastic cycles. Therefore, the cumulative effects of far-fault records are minor.

The modeling results indicate that for two earthquakes with nearly identical conditions, more displacement values are obtained in the near-fault record. Overall and relative displacement increases along with the building height. Nonlinear behavior in taller buildings is more important and nonlinear range is met in less percentile values.

Acknowledgements The author would like to express his gratitude to Dr. Serhan Şensoy for Eastern Mediterranean University in Cyprus for the support provided to develop the research reported in this paper.

Open Access This article is distributed under the terms of the Creative Commons Attribution 4.0 International License (http://crea tivecommons.org/licenses/by/4.0/), which permits unrestricted use, distribution, and reproduction in any medium, provided you give appropriate credit to the original author(s) and the source, provide a link to the Creative Commons license, and indicate if changes were made.

\section{References}

Alavi B, Krawinkler H (2001) Effects of near-fault ground motions on frame structures. Ph.D. Department of Civil and Environmental Engineering Stanford University, California 
Ambraseys NN, Menu JM (1988) Earthquake-induced ground displacement in Europe. Earthq Eng Struct Dyn 16:985-1006

American Society of Civil Engineers (ASCE) (2000) Prestandard and commentary for the seismic rehabilitation of buildings, prepared for the SAC joint venture. Federal Emergency Management Agency, FEMA-356, Washington D.C.

Archuleta RJ, Hartzell SH (1981) Effects of fault finiteness on nearsource ground motion. Bull Seismol Soc Am 71:939-957

Arias A (1970) A measure of earthquake intensity. In: Hansen RJ (ed) Seismic design for nuclear power plants. MIT Press, Cambridge, pp 438-483

Aslani H, Miranda E (2005) Fragility assessment of slab-column connections in existing non-ductile reinforced concrete buildings. J Earthq Eng 9(6):777-804

Baker JW (2015) Efficient analytical fragility function fitting using dynamic structural analysis. Earthq Spectra 31(1):579-599

Berkeley Database (2016) http://nisee.berkeley.edu/data/strong motion/sacsteel/motions/nearfault.html

Bernal D, Döhler M, Kojidi SM, Kwan K, Liu Y (2015) First mode damping ratios for buildings. Earthq Spectra 31(1):367-381. doi:10.1193/101812EQS311M

Bolt BA, Abrahamson NA (1982) New attenuation relations for peak and expected accelerations of strong ground-motion. Bull Seismol Soc Am 72:2307-2321

Bommer JJ (1991) The design and engineering application of an earthquake strong-motion database. Ph.D. thesis, Imperial College, University of London

Bommer JJ, Mendis R (2005) Scaling of spectral displacement ordinates with damping ratios. Earthq Eng Struct Dyn 34(2):145-165

Bray JD, Rodriguez-Marek A (2004) Characterization of forwarddirectivity ground motions in the near-fault region. Soil Dyn Earthq Eng 24(11):815-828

Campbell KW (1981) Near-source attenuation of peak horizontal acceleration. Bull Seismol Soc Am 71:2039-2070

Chopra AK (2012) Dynamics of structures: theory and applications to earthquake engineering, 4th edn. Prentice Hall, Upper Saddle River

Chopra AK, Chintanapakdee C (2001) Comparing response of SDF systems to near-fault and far-fault earthquake motions in the context of spectral regions. Earthq Eng Struct Dyn 30:1769-1789

PEER Strong Motion Database (2016) http://www.peer.berkeley.edu

Elnashai AS, Papazoglou AJ (1997) Procedure and spectra for analysis of RC structures subjected to vertical earthquake loads. J Earthq Eng 1:121-155

Esmaili O, Grant Ludwig L, Zareian F (2015) Improved performancebased seismic assessment of buildings by utilizing Bayesian statistics. Earthq Eng Struct Dyn 45(4):581-597. doi:10.1002/ eqe. 2672

Fragiadakis M, Vamvatsikos D (2011) Qualitative comparison of static pushover versus incremental dynamic analysis capacity curves. In: Proceedings of the 7th hellenic national conference on steel structures, Volos

Hall JF, Heaton TH, Halling MW, Wald DJ (1995) Near-source ground motion and its effects on flexible buildings. Earthq Spectra 11(4):569-605

Hatzigeorgiou G, Liolios A (2010) Nonlinear behaviour of RC frames under repeated strong ground motions. Soil Dyn Earthq Eng 30:1010-1025

Hudson DE (1988) Some recent near-source strong motion accelerograms. In: Proceedings of the ninth world conference on earthquake engineering, vol 2, Tokyo

Ibarra LF, Krawinkler H (2005) Global collapse of frame structures under seismic excitations. In: Technical report 152. The John A. Blume Earthquake Engineering Research Center, Department of Civil Engineering, Stanford University, Stanford
Kalkan E, Kunnath SK (2006) Effects of fling step and forward directivity on seismic response of buildings. Earthq Spectra 22(2):367-390

Komachi Y, Tabeshpour MR (2011) Investigation of directivity effects of near fault records on the response of jacket platforms. In: 11th conference on urban construction in the vicinity of active fault

Krinitzky EL, Chang FK (1987) State of the art for assessing earthquake hazards in the United States: parameters for specifying intensity related earthquake ground motions. US Army Corps of Engineering Waterways Experiment Station, Report 25, New York 25

Lignos DG, Krawinkler H (2009) Sidesway collapse of deteriorating structural systems under seismic excitations. In: Technical report 172. The John A. Blume Earthquake Engineering Research Center, Department of Civil Engineering, Stanford University, Stanford

Martinez-Pereira A (1999) The characterisation of near-field earthquake ground-motions for engineering design. Ph.D. Thesis, Imperial College, University of London

Martinez-Pereira A, Bommer JJ (1998) What is the near-field? Seismic design practice into the next century. Booth editions, Rotterdam, pp 245-252

Mavroeidis G, Papageorgiou A (2003) A mathematical representation of near-fault ground motions. Bull Seismol Soc Am 93(3):1099-1131

Mckenna F, Fenves G, Scott M, Jeremic B (2000) Open system for earthquake engineering simulation. OpenSees, Berkley

Porter K, Kennedy R, Bachman R (2007) Creating fragility functions for performance-based earthquake engineering. Earthq Spectra 23(2):471-489

Rathje EM, Faraj F, Russell S, Bray JD (2004) Empirical relationships for frequency content parameters of earthquake ground motions. Earthq Spectra 20(1):119-144

Sinan A, Ufuk Y, Polat G (2005) Drift estimates in frame buildings subjected to near-fault ground motions. J Struct Eng 131(7):1014-1024

Somerville PG (2003) Magnitude scaling of the near fault rupture directivity pulse. Phys Earth Planet Inter 137:201-212

Somerville PG, Smith NF, Graves RW, Abrahamson NA (1997) Modification of empirical strong ground motion attenuation relations to include the amplitude and duration effects of rupture directivity. Seismol Res Lett 68:199-222

Spyrakos CC, Maniatakis CA, Taflambas J (2008) Evaluation of nearsource seismic records based on damage potential parameters. Soil Dyn Earthq Eng 28:738-753

Stewart JP, Chiou SJ, Bray JD, Graves RW, Somerville PG, Abrahamson NA (2002) Ground motion evaluation procedures for performance-based design. J Soil Dyn Earthq Eng 22:765-772

Tothong P, Cornell CA (2008) Structural performance assessment under near source pulse-like ground motions using advanced ground motion intensity measures. Earthq Eng Struct Dyn 37:1013-1037

Vafaie J, TaghikhanyT, Tehranizadeh M (2011) Near field effect on horizontal equal-hazard spectrum of Tabriz city in north-west of Iran. Int J Civil Eng 9(1)

Vamvatsikos D, Cornell CA (2002) Incremental dynamic analysis. Earthq Eng Struct Dyn 31(3):491-514

Vamvatsikos D, Cornell CA (2004) Applied incremental dynamic analysis. Earthq Spectra 20(2):523-553

Visnjic T, Panagiotou M, Moehle JP (2013) Seismic response of 20 -story tall reinforced concrete special moment resisting frames designed with current code provisions. Earthq Spectra (in press). doi:10.1193/082112EQS267M

Yang DX, Wang W (2012) Nonlocal period parameters of frequency content characterization of near-fault ground motions. Earthq Eng Struct Dyn 41(13):1793-1811 